\title{
Marcin Gospodarowicz
}

Instytut Ekonomiki Rolnictwa i Gospodarki Żywnościowej - Państwowy Instytut Badawczy e-mail: Marcin.Gospodarowicz@ierigz.waw.pl

\section{SPÓJNOŚĆ TERYTORIALNA GMIN W POLSCE POD WZGLECEM ROZWOJU DEMOGRAFICZNEGO ORAZ SPOLECZNO-EKONOMICZNEGO W LATACH 2005-2015 W UJECCIU MIAR AUTOKORELACJI PRZESTRZENNEJ}

\section{TERRITORIAL COHESION OF MUNICIPALITIES \\ IN POLAND (2005-2015) IN TERMS \\ OF SPATIAL AUTOCORRELATION MEASURES \\ OF DEMOGRAPHIC AND SOCIO-ECONOMIC DEVELOPMENT}

DOI: $10.15611 /$ pn.2018.529.08

JEL Classification: R50, R58

Streszczenie: Spójność terytorialna odnosi się do zintegrowanego zarządzania przestrzenią, łagodzącego i zapobiegającego jej polaryzacji. Celem analizy była delimitacja zjawiska spójności terytorialnej pod względem rozwoju demograficznego oraz społeczno-ekonomicznego przy wykorzystaniu statystyki autokorelacji przestrzennej w celu identyfikacji klastrów - skupień gmin o podobnej charakterystyce oraz hot-spots - regionów o wartościach odstających od otoczenia. Badaniem objęto całą populację gmin w Polsce (2478) w latach 2005, 2010 i 2015. Wyniki wskazują na istnienie dodatniej i rosnącej autokorelacji przestrzennej dla miar rozwoju demograficznego i społeczno-gospodarczego w poszczególnych latach. Dla liczebności skupień lokalnych miar statystyki Morana cechami różnicującymi były rodzaj i typ ludnościowy gmin oraz położenie przestrzenne w ujęciu wojewódzkim. Spójność terytorialna, tj. zgodność w przyporządkowaniu do typu skupienia, została zidentyfikowana w niewielkiej części badanych jednostek.

Słowa kluczowe: spójność terytorialna, autokorelacja przestrzenna.

Summary: Territorial cohesion refers to integrated space management, mitigating and preventing its polarization. The aim of the analysis was to delimit the phenomenon of territorial cohesion in terms of demographic and socio-economic development using spatial autocorrelation statistics to identify clusters of municipalities with similar characteristics and hot spots - regions with outliers in relation to the environment. The analysis covered the entire population of communes in Poland (2478), in 2005, 2010 and 2015. The results indicate the existence of positive and increasing spatial autocorrelation for the measures of demographic 
and socio-economic development in particular years. For the number of clusters of local Moran statistics, the differentiating features were the type and population of communes and the spatial location in voivodship. Territorial cohesion, ie. compliance in relation to the type of cluster has been identified in a small part of the surveyed units.

Keywords: territorial cohesion, spatial autocorrelation.

\section{Wstęp}

Pojęcie spójności terytorialnej odnosi się do zintegrowanego zarządzania przestrzenią, które łagodzi i zapobiega jej polaryzacji. Jest ono ujmowane w inny sposób w dokumentach strategicznych UE (tj. na poziomie europejskim), a inaczej na poziomie krajowym. Z perspektywy europejskiej koncepcja ta dotyczy raczej wyrównywania poziomu rozwoju pomiędzy poszczególnymi krajami/regionami, tj. zbliżenia bądź konwergencji, która wiąże się ze wsparciem finansowym z UE z wykorzystaniem funduszy spójności, w szczególności dla regionów o najniższym poziomie rozwoju. Spójność terytorialna w wewnętrznej polityce kraju odnosi się głównie do wymiaru przestrzennego, w kontekście niedopuszczenia do nadmiernych zróżnicowań przestrzennych (wewnątrz regionów, a także pomiędzy regionami) [Polski 2015; Ryszkiewicz 2013]. Cechy demograficzne i charakterystyki społeczno-gospodarcze są ważnymi czynnikami wspierania procesu spójności terytorialnej, ze względu na swoje ścisłe powiązanie z obszarem, jako specyficzne zasoby wpływające na rozwój. Znaczenie wymienionych cech $\mathrm{w}$ rozwoju terytorium podkreślane jest $\mathrm{w}$ wielu teoriach zagospodarowania przestrzennego (m.in. teorii biegunów wzrostu, teorii centrum - peryferie, teorii rozwoju lokalnego), a także analizowane w badaniach empirycznych.

Celem prezentowanej analizy była delimitacja zjawiska spójności terytorialnej pod względem rozwoju demograficznego oraz społeczno-ekonomicznego na obszarach wiejskich w stosunku do miast, a także wskazanie obszarów dotkniętych polaryzacją rozwoju w wyżej wspomnianym zakresie. Zgodnie z zasadami budowy statystyk autokorelacji przestrzennej umożliwia to identyfikację klastrów (skupień) gmin o podobnej charakterystyce oraz hot-spots regionów o wartościach odstających $\mathrm{w}$ stosunku do otoczenia. Przyjęto przy tym założenie, iż zgodnie z zasadą kołowego i kumulatywnego związku przyczynowego Myrdala [Myrdal 1958] zmiana poszczególnych cech rozwoju demograficznego oraz charakterystyk społeczno-ekonomicznych powoduje zmiany w innych elementach charakteryzujących region, sprzężenie zwrotne między nimi intensyfikuje interakcje, zaś głębokie lokalne przekształcenia mogą stanowić przyczynę nierówności (dywergencji), które trudno jest odwrócić, co prowadzi do marginalizacji. Założono ponadto, że szczególnie duże miasta wywierają istotny wpływ na przestrzenne zróżnicowanie obszarów położonych w dotkniętej strefie. W ujęciu dwuwymiarowym podjęto również próbę jednoczesnej oceny spójności terytorialnej badanych regionów pod kątem kształtowania się wartości obu badanych cech. 
Zakres przestrzenny badań obejmował 2478 gmin na terenie Polski, w tym 303 gminy miejskie, 583 gminy miejsko-wiejskie i 1592 gminy wiejskie, w latach 2005, 2010 i 2015.

\section{Metodologia badań - wskaźniki autokorelacji przestrzennej}

Do oceny poziomu rozwoju demograficznego oraz społeczno-ekonomicznego wykorzystano metodę Z. Hellwiga [1968]. Syntetyczne wskaźniki agregowały miary liczby populacji (w ujęciu bezwzględnym i dynamicznym na przestrzeni czasu), przyrostu naturalnego, salda migracji (globalnego oraz w ujęciu miasto-wieś), współczynników obciążenia społecznego i demograficznego dla miary rozwoju demograficznego oraz charakterystyki rynku pracy, przedsiębiorczości oraz zamożności i skłonności inwestycyjnej gmin w przypadku miary rozwoju społeczno-gospodarczego. W oparciu o wartości przeciętne wskaźnika syntetycznego oszacowano wartości globalnej oraz lokalnej statystyki Morana opisującej autokorelację przestrzenną gmin.

\subsection{Pojęcie i pomiar autokorelacji przestrzennej}

Autokorelacja przestrzenna definiowana jest jako wpływ zjawiska występującego $\mathrm{w}$ jednostce przestrzennej na prawdopodobieństwo jego stwierdzenia $\mathrm{w}$ sąsiednich formacjach przestrzennych. Jest to zatem miara homogeniczności struktur przestrzennych, która może być klasyfikowana jako dodatnia (pozytywna), ujemna (negatywna) lub zerowa (brak autokorelacji). Autokorelacja dodatnia oznacza przestrzenne tworzenie klastrów (skupień) wysokich lub niskich wartości obserwowanych zmiennych. Ujemna autokorelacja oznacza sąsiadowanie w przestrzeni wartości wysokich z wartościami niskimi, a niskich z wysokimi, czego obrazem graficznym jest wzór szachownicy. Brak autokorelacji przestrzennej jest tożsamy z przestrzenną losowością, gdy rozmieszczenie wartości wysokich i niskich zmiennych jest całkowicie niezależnie [Kopczewska 2006].

Statystyka przestrzenna wykorzystuje globalne (wskazujące na istnienie korelacji w obrębie całej badanej populacji) i lokalne (opisujące zależności przestrzenne wybranego podmiotu z jednostkami sąsiadującymi) wskaźniki autokorelacji przestrzennej. Popularne miary autokorelacji przestrzennej to globalna statystyka $I$ Morana oraz wskaźniki lokalne LISA [Janc 2006].

Globalna statystyka $I$ Morana opisana jest za pomocą formuły:

$$
I=\frac{n \sum_{i=1}^{n} \sum_{j=1}^{n} w_{i j}\left(x_{i}-\bar{x}\right)\left(x_{j}-\bar{x}\right)}{\sum_{i=1}^{n} \sum_{j=1}^{n} w_{i j} \cdot \sum_{i=1}^{n}\left(x_{i}-\bar{x}\right)^{2}}=\frac{n}{S_{0}} \cdot \frac{Z^{T} W z}{Z^{T} z},
$$

gdzie $x_{i}$ oraz $x_{j}$ opisują wartości analizowanych zmiennych w jednostkach przestrzennych $i$ oraz $j, \bar{x}$ to średnia arytmetyczna wartości dla wszystkich $n$ analizowa- 
nych jednostek przestrzennych, $S_{0}$ to suma wszystkich elementów macierzy wag, $\mathbf{z}$ to wektor kolumnowy o elementach $z_{i}=x_{i}-\bar{x}, \mathbf{W}$ to macierz wag przestrzennych $n$-stopnia, która opisuje strukturę sąsiedztwa ${ }^{1}$, zaś $w_{i j}$ to element zero-jedynkowej macierzy wag $\mathbf{W}$.

Istotność statystyczną autokorelacji przestrzennej można zweryfikować za pomocą unormowanej statystyki $I_{s} \sim N(0,1)$. Może ona przyjmować wartości:

$I \approx-1 /(n-1), I \approx 0 \rightarrow$ oznaczający brak autokorelacji;

$I>-1 /(n-1), I_{s}>0 \rightarrow$ oznaczający autokorelację dodatnią;

$I<-1 /(n-1), I_{s}<0 \rightarrow$ oznaczający autokorelację ujemną.

Interpretacja współczynnika autokorelacji przestrzennej zbliżona jest do klasycznego współczynnika korelacji liniowej. Jednoczynnikowa miara Morana $I$ to globalna statystyka, która informuje o istnieniu klastra bądź rozproszeniu danych, ale nie podaje lokalizacji klastra. Lokalna miara $I_{i}$ Morana to statystyka autokorelacji przestrzennej opracowana przez Anselina [1995] jako lokalny wskaźnik powiązań przestrzennych (LISA). Za pomocą lokalnej statystyki Morana $I_{i}$ LISA możliwe jest wyznaczenie skupisk jednostek przestrzennych i dokonanie oceny, czy wybrana jednostka otoczona jest przez podmioty o podobnych, czy różnych wartościach badanych cech w relacji do losowego rozkładu w badanej przestrzeni. Rozkłada ona wartości globalnej statystyki Morana na komponenty, tworząc w ten sposób mapę $\mathrm{z}$ regionami (klastrami), które mają wysokie wartości zmiennej, otoczonymi sąsiadami o wysokich wartościach (high-high $\mathrm{HH}$ ), regiony o niskich wartościach otoczone sąsiadami o niskich wartościach (low-low LL) oraz pary low-high LH i high-low HL, tj. jednostki otoczone podmiotami o odmiennych charakterystykach badanej zmiennej. Klastry, tj. regiony zgodności, w znacznym stopniu przyczyniają się do pozytywnego wyniku globalnej autokorelacji przestrzennej, podczas gdy niezgodności (tzw. hot-spoty) znacząco obniżają autokorelację. Lokalna statystyka $I_{i}$ Morana opisana jest za pomocą formuly:

$$
I_{i}=\frac{\left(x_{i}-\bar{x}\right) \sum_{j=1}^{n} w_{i j}\left(x_{j}-\bar{x}\right)}{\sum_{i=1}^{n} \frac{\left(x_{i}-\bar{x}\right)^{2}}{n}},
$$

gdzie definicje symboli są identyczne $\mathrm{z}$ wykorzystanymi $\mathrm{w}$ formule globalnej statystyki Morana $I$. Istotność statystyczna autokorelacji przestrzennej weryfikowana jest za pomocą zaproponowanej przez L. Anselina standaryzowanej wersji lokalnej statystyki Morana. Ujemna autokorelacja (i wartość statystyki) oznacza, iż analizowany obiekt jest otoczony przez jednostki przestrzenne o znacząco odmiennych wartościach badanej zmiennej (hot-spots), zaś w przypadku dodatniej autokorelacji przestrzennej (i wartości statystyki) obiekt jest otoczony przez podobne jednostki

${ }^{1}$ Popularne definicje sąsiedztwa obejmują pasma odległości (na przykład jednostki w odległości $\mathrm{X}$ km) i $k$ najbliższych sąsiadów (np. 2 najbliższych sąsiadów). Do oszacowania macierzy wag przestrzennych wymagana jest znajomość położenia jednostki w przestrzeni, tj. współrzędnych geograficznych. 
(tj. tworzą się klastry bądź skupienia obiektów). Reprezentacja graficzna wyników analizy przy wykorzystaniu globalnej statystyki Morana przyjmuje postać dwuwymiarowego wykresu rozproszenia (scatterplot diagramm), w którym opóźnienie przestrzenne reszt regresji cechy jest funkcją standaryzowanych wartości reszt z klasycznego modelu regresji. Globalny charakter wskaźnika autokorelacji w całej populacji można odczytać na podstawie nachylenia linii regresji. W piśmiennictwie krajowym miary autokorelacji lokalnej na poziomie gmin były wykorzystywane m.in. do analizy dyfuzji rozwoju z miast metropolitalnych i identyfikacji obszarów dotkniętych polaryzacją w kontekście dochodów jednostkowych budżetów gmin [Herbst, Wójcik 2013].

\section{Wyniki i analiza uzyskanych oszacowań}

Oszacowana globalna statystyka $I$ Morana dla badanej populacji w kolejnych latach w przypadku obydwu cech miała wartości dodatnie i istotne statystycznie (rys. 1). Oznacza to istnienie dodatniej autokorelacji przestrzennej w poszczególnych latach, czyli skupianie się obszarów (gmin) o podobnych charakterystykach infrastrukturalnych i demograficznych oraz wskaźnikach rozwoju społeczno-gospodarczego.

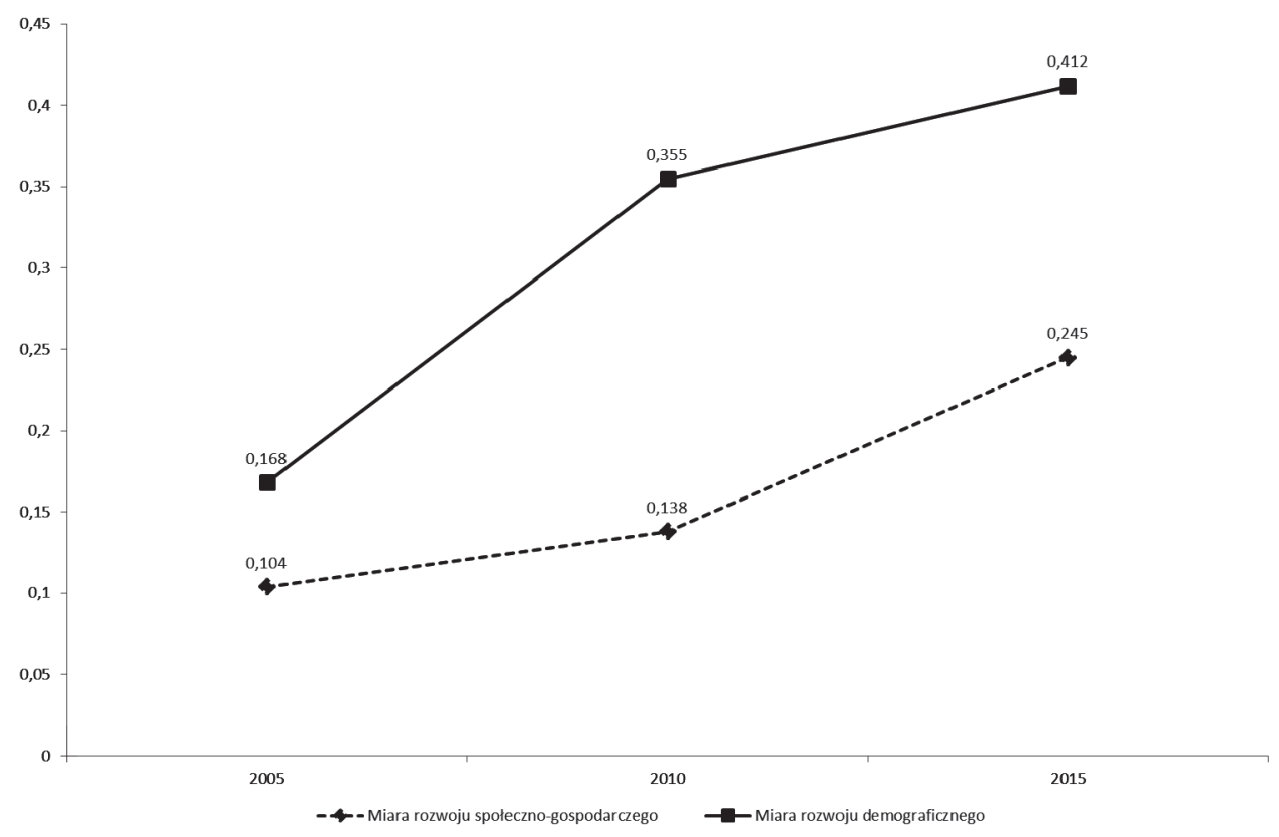

Rys. 1. Wartości globalnej statystyki Morana dla zagregowanych indeksów rozwoju demograficznego oraz społeczno-gospodarczego w latach 2005, 2010 i 2015

Źródło: opracowanie własne na podstawie Banku Danych Lokalnych. 
Jednocześnie rosnąca tendencja wartości rozważanej statystyki, w całym rozpatrywanym okresie 2005-2015, oznacza wzmocnienie zależności przestrzennej.

Dodatnia autokorelacja, tj. skłonności do budowy klastrów przestrzennych, była szczególnie wysoka w przypadku cech demograficznych, zarówno w ujęciu bezwzględnym, jak i w przypadku dynamiki zjawiska. Wzrost wartości globalnej statystyki $I$ Morana na przestrzeni lat świadczy o silnie zachodzącym procesie konwergencji rozwojowej w badanym obszarze. Wzrost ten oznacza, że nastąpiło wzmocnienie zależności przestrzennych. Na podstawie raportowanych wartości można odczytywać tendencje większej polaryzacji badanych regionów w przestrzeni geograficznej i większej przestrzennej heterogeniczności zjawisk w przypadku cech społeczno-gospodarczych wobec większej i rosnącej ich homogeniczności w przypadku cech demograficznych.

Analiza wskaźników zależności przestrzennych w ujęciu wartości lokalnej statystyki $I_{i}$ Morana wykazała wartości istotne dla 436 gmin w roku 2005, 527 w 2010 oraz 503 w 2015 dla miary rozwoju demograficznego oraz 511 w roku 2005, 521 w 2010 i 548 w 2015 dla miar rozwoju społeczno-gospodarczego. Proporcje te pozostają zatem na relatywnie stałym poziomie w okresie analizy. Dane zaprezentowane na rys. 2 wskazują jednak na odmienne kształtowanie się liczby i dynamiki klastrów i hot-spotów w poszczególnych latach oraz w wymiarze obu analizowanych charakterystyk.

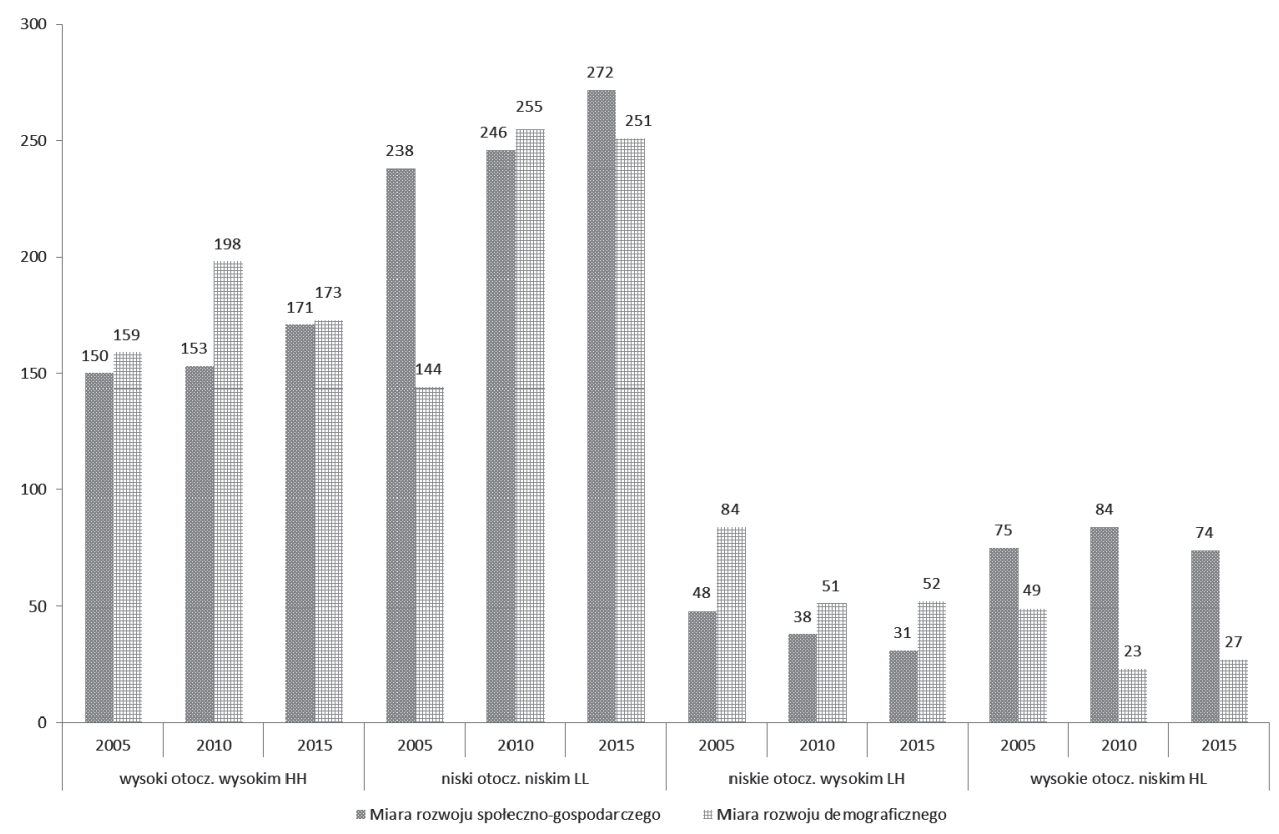

Rys. 2. Liczba gmin należących do klastrów i hot-spotów przestrzennych w latach 2005, 2010 i 2015 (na podstawie wartości lokalnej statystyki Morana)

Źródło: opracowanie własne na podstawie Banku Danych Lokalnych. 
Analiza dynamiki zjawiska wskazuje, iż w odniesieniu do charakterystyk demograficznych badanych gmin liczba klastrów typu HH wzrosła niemal o $25 \%$ w okresie 2005-2010, a następnie obniżyła się o 13\%.

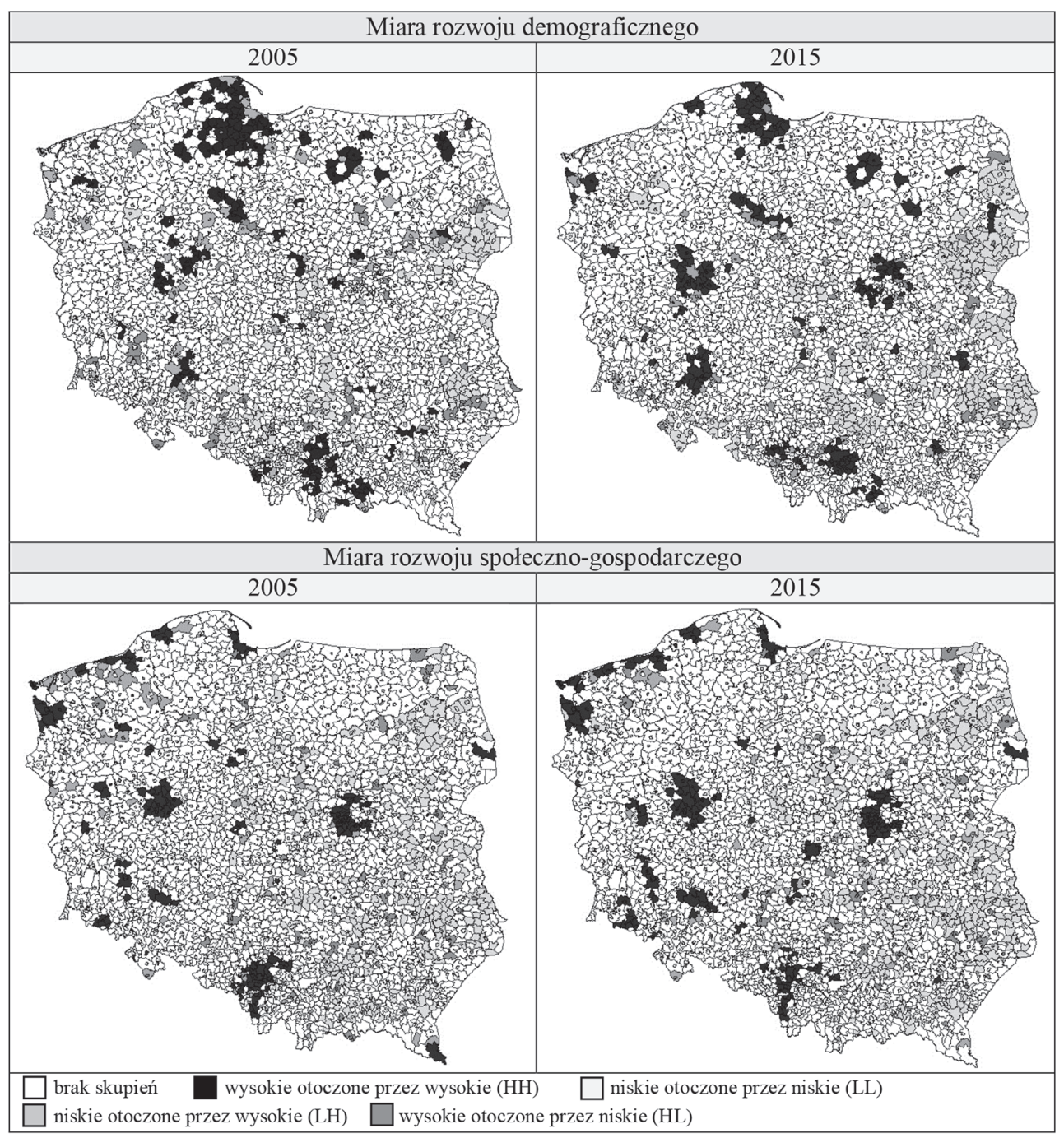

Rys. 3. Liczba gmin należących do klastrów i hot-spotów przestrzennych w latach 2005 i 2015 (na podstawie wartości lokalnej statystyki Morana)

Źródło: opracowanie własne na podstawie Banku Danych Lokalnych.

W przypadku rozwoju społeczno-gospodarczego dynamika tworzenia klastrów HH była dodatnia w całym okresie analizy i wyniosła 2\% w latach 2005-2010 oraz 
12\% w latach 2010-2015. Liczba klastrów typu LL wzrosła w przypadku agregatowych charakterystyk demograficznych o 77\% w latach 2005-2010, aby następnie zanotować nieznaczny spadek (o 1,6\%) w kolejnej pięciolatce.

Dla charakterystyk społeczno-demograficznych liczba klastrów tego typu nieprzerwanie rosła - o niemal 4\% w latach 2005-2010, a następnie o $11 \%$ w kolejnym badanym okresie pięcioletnim. W tym przypadku można mówić o niekorzystnym procesie tworzenia się nowych klastrów przestrzennych złożonych z gmin o niskim poziomie rozwoju społeczno-gospodarczego. W przypadku tzw. hot-spotów, czyli gmin otoczonych jednostkami o odmiennych charakterystykach, brak jest jednolitego wzorca rozwoju zjawiska. W odniesieniu do cech demograficznych liczba hot-spotów spadła niemal o połowę w okresie 2005-2010 (LH o 40\%, a HL o 53\%), aby w kolejnym badanym przedziale czasowym zanotować niewielki wzrost (z 74 do 79). Dla miary rozwoju społeczno-gospodarczego liczba skupień typu LH spadła o 21\% w okresie 2005-2010 oraz 19\% w latach 2010-2015, zaś liczba skupień typu HL powróciła w roku 2015 do poziomu z roku 2005. Może to wskazywać na sytuację, gdy zróżnicowanie relacji przestrzennych w zakresie rozwoju społeczno-gospodarczego i w szczególności demograficznego relatywnie maleje.

W ujęciu przestrzennym po nałożeniu gmin na siatkę wojewódzką (tab. 1) widoczne jest, iż lokalne klastry typu HH w przypadku miary rozwoju demograficznego przeważają na terenie województw: pomorskiego, małopolskiego, mazowieckiego, wielkopolskiego i dolnośląskiego, zaś dla miary rozwoju społeczno-gospodarczego na terenie województw: mazowieckiego, śląskiego, wielkopolskiego, dolnośląskiego, zachodniopomorskiego i pomorskiego. Z kolei dla klastrów typu LL główna lokalizacja obejmuje tereny województw: lubelskiego, podlaskiego, świętokrzyskiego, łódzkiego i mazowieckiego w przypadku miary rozwoju demograficznego oraz województwa: lubelskie, mazowieckie, podlaskie, świętokrzyskie, podkarpackie i małopolskie w przypadku miary rozwoju społeczno-gospodarczego.

Można zatem wnioskować w przypadku cech charakteryzujących rozwój społeczno-gospodarczy, iż gminy o wysokim natężeniu cechy zgrupowane były przede wszystkim w otoczeniu wielkich miast i ośrodków przemysłowych, na obszarze województw zachodniej, centralnej i północnej Polski, gminy zaś o niskim poziomie rozwoju położone były przede wszystkim na terenie województw południowo-wschodnich. Wyniki te są zatem zgodne z ogólnymi tendencjami dotyczącymi np. zamożności i wskaźników rozwoju gospodarczego gmin w Polsce. W przypadku miary rozwoju demograficznego trudno określić jednolitą tendencję rozwoju wskaźnika w ujęciu przestrzennym.

Powyższe konstatacje można potwierdzić, analizując reprezentację graficzną (w postaci mapy) rozkładu liczby gmin należących do poszczególnych typów skupień - klastrów bądź hot-spotów. W odniesieniu do miar rozwoju demograficznego układ gmin zaprezentowany na rys. 3, obejmujący lata 2005 i 2015, można uznać za rozproszony i pozbawiony jednolitego wzorca. Brak jest delimitacji pomiędzy obszarami klastrów typu HH i LL, są one rozlokowane na terenie całego kraju. W prze- 
Tabela 1. Liczebność gmin w poszczególnych skupieniach w ujęciu rodzajowym i przestrzennym

\begin{tabular}{|c|c|c|c|c|c|c|c|c|c|c|c|c|c|c|c|c|c|c|c|c|c|c|c|c|}
\hline Rok & \multicolumn{8}{|c|}{2005} & \multicolumn{8}{|c|}{2010} & \multicolumn{8}{|c|}{2015} \\
\hline Skupienie & \multicolumn{2}{|c|}{$\mathrm{HH}$} & \multicolumn{2}{|c|}{ LL } & \multicolumn{2}{|c|}{ LH } & \multicolumn{2}{|c|}{$\mathrm{HL}$} & \multicolumn{2}{|c|}{$\mathrm{HH}$} & \multicolumn{2}{|c|}{ LL } & \multicolumn{2}{|c|}{$\mathrm{LH}$} & \multicolumn{2}{|c|}{$\mathrm{HL}$} & \multicolumn{2}{|c|}{$\mathrm{HH}$} & \multicolumn{2}{|c|}{ LL } & \multicolumn{2}{|c|}{$\mathrm{LH}$} & \multicolumn{2}{|c|}{ HL } \\
\hline Cecha* & $\mathrm{S}$ & $\mathrm{D}$ & $\mathrm{S}$ & $\mathrm{D}$ & $\mathrm{S}$ & $\mathrm{D}$ & $\mathrm{S}$ & $\mathrm{D}$ & $\mathrm{S}$ & $\mathrm{D}$ & $\mathrm{S}$ & $\mathrm{D}$ & $\mathrm{S}$ & $\mathrm{D}$ & $\mathrm{S}$ & $\mathrm{D}$ & $\mathrm{S}$ & $\mathrm{D}$ & $\mathrm{S}$ & $\mathrm{D}$ & $\mathrm{S}$ & $\mathrm{D}$ & $\mathrm{S}$ & $\mathrm{D}$ \\
\hline 1 & 2 & 3 & 4 & 5 & 6 & 7 & 8 & 9 & 10 & 11 & 12 & 13 & 14 & 15 & 16 & 17 & 18 & 19 & 20 & 21 & 22 & 23 & 24 & 25 \\
\hline \multicolumn{25}{|c|}{ Rodzaj i typ ludnościowy gminy } \\
\hline Najmniejsze & 9 & 2 & 1 & 2 & & 1 & 6 & 2 & 11 & 3 & 2 & 4 & & 2 & 6 & 3 & 9 & 1 & 4 & 11 & 1 & 3 & 5 & 1 \\
\hline Małe & 13 & & & 2 & & 5 & 14 & & 10 & 4 & & 4 & 1 & 3 & 18 & & 12 & 2 & & 4 & & 3 & 17 & 1 \\
\hline Średnie & 19 & 6 & & 5 & & 15 & 15 & 1 & 17 & 15 & & 3 & & 2 & 14 & 1 & 17 & 16 & & 3 & & 3 & 15 & 1 \\
\hline Duże & 11 & 3 & & 5 & & 9 & 5 & & 9 & 7 & & 1 & & 3 & 8 & & 10 & 5 & & & & 7 & 8 & \\
\hline Największe & 14 & 1 & & 4 & & 12 & 1 & 1 & 16 & 5 & & & & 11 & & & 14 & 8 & & & & 10 & & \\
\hline Miejskie & 66 & 12 & 1 & 18 & 0 & 42 & 41 & 4 & 63 & 34 & 2 & 12 & 1 & 21 & 46 & 4 & 62 & 32 & 4 & 18 & 1 & 26 & 45 & 3 \\
\hline Najmniejsze & 2 & 1 & 10 & 8 & 1 & & & 1 & & & 9 & 16 & 2 & & & & & & 11 & 16 & 1 & 1 & & 1 \\
\hline Małe & 4 & 18 & 80 & 48 & 14 & 4 & 2 & 5 & 5 & 13 & 94 & 111 & 13 & 5 & 3 & 4 & 9 & 7 & 98 & 103 & 8 & 3 & & 5 \\
\hline Średnie & 17 & 48 & 80 & 41 & 16 & 9 & 2 & 13 & 17 & 53 & 85 & 64 & 15 & 10 & 2 & 5 & 22 & 41 & 95 & 56 & 12 & 5 & & 5 \\
\hline Duże & 15 & 27 & 12 & 4 & 5 & 6 & & 7 & 15 & 27 & 11 & 2 & 2 & 2 & 1 & 2 & 20 & 27 & 11 & 1 & 2 & 1 & 1 & 6 \\
\hline Największe & 15 & 16 & 2 & 2 & & 1 & 1 & 4 & 17 & 22 & & 1 & 1 & & 1 & 1 & 19 & 23 & & & & 1 & 1 & 2 \\
\hline Wiejskie & 53 & 110 & 184 & 103 & 36 & 20 & 5 & 30 & 54 & 115 & 199 & 194 & 33 & 17 & 7 & 12 & 70 & 98 & 215 & 176 & 23 & 11 & 2 & 19 \\
\hline Najmniejsze & 1 & 2 & 4 & 2 & & 2 & & & 1 & 1 & 4 & 2 & & & 1 & 1 & 1 & 1 & 4 & 3 & & & 2 & \\
\hline Małe & 2 & 5 & 19 & 6 & 6 & 3 & 2 & 4 & 4 & & 18 & 16 & 2 & 4 & 3 & 1 & 5 & & 18 & 19 & 3 & 2 & 2 & \\
\hline Średnie & 7 & 11 & 22 & 11 & 2 & 7 & 17 & 6 & 6 & 11 & 18 & 20 & & 3 & 15 & 1 & 8 & 7 & 20 & 22 & 3 & 3 & 13 & 2 \\
\hline Duże & 11 & 14 & 8 & 4 & 3 & 5 & 8 & 5 & 14 & 24 & 5 & 10 & 1 & 4 & 10 & 4 & 13 & 20 & 11 & 11 & 1 & 7 & 8 & 3 \\
\hline Największe & 10 & 5 & & & 1 & 5 & 2 & & 11 & 13 & & 1 & 1 & 2 & 2 & & 12 & 15 & & 2 & & 3 & 2 & \\
\hline $\begin{array}{l}\text { Miejsko- } \\
\text {-wiejskie }\end{array}$ & 31 & 37 & 53 & 23 & 12 & 22 & 29 & 15 & 36 & 49 & 45 & 49 & 4 & 13 & 31 & 7 & 39 & 43 & 53 & 57 & 7 & 15 & 27 & 5 \\
\hline
\end{tabular}


Tabela 1, cd.

\begin{tabular}{|c|c|c|c|c|c|c|c|c|c|c|c|c|c|c|c|c|c|c|c|c|c|c|c|c|}
\hline 1 & 2 & 3 & 4 & 5 & 6 & 7 & 8 & 9 & 10 & 11 & 12 & 13 & 14 & 15 & 16 & 17 & 18 & 19 & 20 & 21 & 22 & 23 & 24 & 25 \\
\hline \multicolumn{25}{|c|}{ Województwo } \\
\hline Dolnośląskie & 17 & 8 & & 2 & 2 & 8 & & 8 & 22 & 15 & & 6 & 4 & 6 & 1 & & 27 & 15 & & 17 & 6 & 6 & & 4 \\
\hline $\begin{array}{l}\text { Kujawsko- } \\
\text {-pomorskie }\end{array}$ & 3 & 7 & 10 & 1 & & 8 & 6 & 2 & 3 & 12 & 9 & 2 & 1 & 5 & 4 & 1 & 2 & 8 & 7 & 1 & 1 & 5 & 3 & 3 \\
\hline Lubelskie & & & 74 & 29 & 2 & 2 & 14 & 7 & & 1 & 77 & 73 & 4 & 3 & 19 & 6 & & 4 & 95 & 81 & 1 & 2 & 18 & 7 \\
\hline Lubuskie & 3 & & & & 3 & & & & 1 & 1 & & & 1 & 1 & & & 1 & 2 & & & 1 & 1 & & \\
\hline Łódzkie & 4 & 2 & 12 & 14 & 5 & 2 & 3 & 2 & 8 & 2 & 15 & 40 & 5 & & 1 & 3 & 11 & 3 & 12 & 20 & 6 & 3 & 2 & 2 \\
\hline Małopolskie & 5 & 37 & 26 & 5 & 3 & 6 & 10 & 2 & 6 & 38 & 17 & 4 & 1 & 2 & 9 & 2 & 5 & 30 & 14 & 7 & 3 & 3 & 5 & \\
\hline Mazowieckie & 33 & 9 & 35 & 12 & 4 & 12 & 13 & 4 & 34 & 39 & 48 & 22 & 5 & 12 & 16 & 2 & 38 & 31 & 47 & 26 & 2 & 8 & 14 & 1 \\
\hline Opolskie & & & & 12 & & & 2 & 6 & & & & 11 & & & 2 & & 1 & & & 9 & & & 2 & 2 \\
\hline Podkarpackie & 1 & 7 & 19 & 6 & 2 & 5 & 6 & 2 & & & 18 & & 3 & 1 & 4 & & 1 & 2 & 29 & & 1 & 3 & 7 & \\
\hline Podlaskie & & 1 & 27 & 20 & 1 & 2 & 6 & 6 & & 2 & 27 & 48 & & & 7 & 5 & & 3 & 33 & 47 & & & 7 & 4 \\
\hline Pomorskie & 11 & 50 & 1 & & 2 & 13 & 1 & & 13 & 48 & 4 & & 1 & 7 & 3 & & 14 & 32 & 3 & & 1 & 5 & 2 & \\
\hline Śląskie & 37 & 6 & 2 & 19 & 9 & 2 & 1 & 5 & 29 & 8 & 1 & 9 & 4 & 2 & 1 & 1 & 25 & 9 & 1 & 5 & 2 & 5 & 1 & 3 \\
\hline Świętokrzyskie & & 2 & 23 & 23 & 1 & 2 & 6 & 4 & & & 18 & 38 & 1 & 1 & 6 & 3 & & 1 & 20 & 31 & 1 & 1 & 5 & 1 \\
\hline $\begin{array}{l}\text { Warmińsko- } \\
\text {-mazurskie }\end{array}$ & & 11 & 2 & & 1 & 4 & 4 & & 2 & 7 & 3 & & & 2 & 6 & & & 8 & 5 & 1 & 1 & 1 & 6 & \\
\hline Wielkopolskie & 20 & 15 & 6 & & 5 & 10 & 2 & 1 & 20 & 21 & 7 & 2 & 3 & 7 & 2 & & 25 & 22 & 5 & 2 & 3 & 8 & & \\
\hline $\begin{array}{l}\text { Zachodnio- } \\
\text { pomorskie }\end{array}$ & 16 & 4 & 1 & 1 & 8 & 8 & 1 & 8 & 15 & 4 & 2 & & 5 & 2 & 3 & & 21 & 3 & 1 & 4 & 2 & 1 & 2 & \\
\hline
\end{tabular}

* D - miara rozwoju demograficznego, S - miara rozwoju społeczno-gospodarczego, populacja (w tys.) w rodzajach i typach ludnościowych gmin: miejskie - najmniejsze $(<10)$, małe (10-20), średnie (20-50), duże (50-100), największe $(>100)$; wiejskie - najmniejsze $(<2,5)$, małe $(2,5-5)$, średnie (5-10), duże (10-15), największe (> 15); miejsko-wiejskie - najmniejsze $(<5)$, małe (5-7,5), średnie (7,5-15), duże (15-30), największe (> 30)

Źródło: opracowanie własne na podstawie Banku Danych Lokalnych. 
ciwieństwie do tego, w przypadku miary rozwoju społeczno-gospodarczego obszary występowania klastrów wysokiego i niskiego rozwoju są rozgraniczone w sposób wyraźny i podzielone pomiędzy zachodnią i wschodnią część terytorium Polski. W przypadku danych o rozwoju społeczno-gospodarczym widoczne jest również zgrupowanie hot-spotów - gmin o wysokich wartościach cechy otoczonych niskimi na terenie województw lubelskiego, mazowieckiego i małopolskiego.

W ujęciu rodzaju i wielkości gminy (tab. 1) można w odniesieniu do miary rozwoju społeczno-gospodarczego wskazać na istotną prawidłowość, zgodnie z którą klastry o wysokiej wartości cechy $(\mathrm{HH})$ stwierdzić można w pierwszej kolejności na obszarze gmin miejskich (bez względu na wielkość) oraz w gminach wiejskich i miejsko-wiejskich o najwyższym potencjale ludnościowym. Zasada ta zachowuje ważność w całym okresie analizy (2005-2015). Klastry o niskiej wartości cechy (LL) zaobserwować można przede wszystkim na terenie małych gmin wiejskich i w mniejszym stopniu w małych gminach miejsko-wiejskich. Również ta relacja utrzymuje się w całym okresie badania. W gminach miejskich nie powstawały prawie żadne klastry LL, stwierdzono natomiast $\mathrm{w}$ tej grupie stosunkowo dużą liczbę hot-spotów typu HL. W 2015 było 45 takich jednostek, położonych przede wszystkim na terenie województw: lubelskiego, mazowieckiego, małopolskiego i podkarpackiego. W przypadku miary rozwoju demograficznego trudno jest uchwycić jednolite wzorce w odniesieniu do rodzaju skupienia na tle typu i wielkości gminy, choć można zauważyć, iż większość zarejestrowanych klastrów zarówno wartości wysokich (HH), jak i niskich (LL) znajduje się na terenie gmin wiejskich o średnim i dużym potencjale ludnościowym.

Tabela 2. Miary zależności pomiędzy skupieniami dla poszczególnych miar rozwoju (2005-2015)*

\begin{tabular}{|c|c|c|c|c|c|c|}
\hline & D2005 & D2010 & D2015 & S2005 & S2010 & S2015 \\
\hline \multirow[t]{2}{*}{ D2005 } & & $\chi^{2}=989,9$ & $\chi^{2}=1099,3$ & $\chi^{2}=117,68$ & $\chi^{2}=114,58$ & $\chi^{2}=118,07$ \\
\hline & & $\mathrm{VC}=0,316$ & $\mathrm{VC}=0,333$ & $\mathrm{VC}=0,109$ & $\mathrm{VC}=0,108$ & $\mathrm{VC}=0,109$ \\
\hline \multirow[t]{2}{*}{ D2010 } & & & $\chi^{2}=3331,1$ & $\chi^{2}=299,73$ & $\chi^{2}=376,96$ & $\chi^{2}=427,56$ \\
\hline & & & $\mathrm{VC}=0,58$ & $\mathrm{VC}=0,174$ & $\mathrm{VC}=0,195$ & $\mathrm{VC}=0,208$ \\
\hline \multirow[t]{2}{*}{ D2015 } & & & & $\chi^{2}=342,84$ & $\chi^{2}=412,4$ & $\chi^{2}=447,04$ \\
\hline & & & & $\mathrm{VC}=0,186$ & $\mathrm{VC}=0,204$ & $\mathrm{VC}=0,212$ \\
\hline \multirow[t]{2}{*}{ S2005 } & & & & & $\chi^{2}=5215,8$ & $\chi^{2}=4111$ \\
\hline & & & & & $\mathrm{VC}=0,725$ & $\mathrm{VC}=0,644$ \\
\hline \multirow[t]{2}{*}{ S2010 } & & & & & & $\chi^{2}=4704,8$ \\
\hline & & & & & & $\mathrm{VC}=0,689$ \\
\hline S2015 & & & & & & \\
\hline
\end{tabular}

* D - miara rozwoju demograficznego, $\mathrm{S}$ - miara rozwoju społeczno-gospodarczego, VC - miara V-Cramera

Źródło: opracowanie własne na podstawie Banku Danych Lokalnych. 
Analizę zależności pomiędzy poziomem rozwoju demograficznego a poziomem rozwoju społeczno-gospodarczego w ujęciu zidentyfikowanych jednorodnych skupień gmin oparto na tabelach kontyngencji, zaś miara statystyczna wykorzystana do wnioskowania o zależności bądź jej braku to klasyczny test badania zgodności cech mierzalnych i niemierzalnych $\chi^{2}$ na poziomie istotności $1 \%$. Podstawą oceny kierunku i siły zależności pomiędzy cechami był współczynnik asocjacji V-Cramera, który może być stosowany do wszelkiego typu danych o charakterze nieciągłym, tj. zarówno typu nominalnego, jak i binarnego oraz uporządkowanego. Zakres wartości współczynnika V-Cramera zawiera się od 0 (wskazującego na bezwzględny brak zależności) do 1 (wskazującego na kompletną zależność). W założeniu wyższe wartości współczynnika V-Cramera wskazują na silniejszy związek dwóch analizowanych cech [King, Minium 2009]. Współczynniki zależności V-Cramera pomiędzy obiema cechami charakteryzują się stosunkowo niskimi wartościami - 0,109 w 2005, 0,195 w 2010 oraz 0,212 w 2015 (tab. 2), co świadczy o niewielkiej zależności pomiędzy nimi, a zatem o ograniczonym zakresie spójności terytorialnej. Odnotować należy jednak wzrost tego wskaźnika w okresie analizy, co może wskazywać na zmianę sytuacji i ograniczony wzrost spójności w latach 2005-2015. W roku 2005 zidentyfikowano 50 gmin, które znalazły się w takich samych skupieniach (tj. klastrach bądź hot-spotach odpowiedniego typu) zarówno w odniesieniu do miary demograficznej, jak i wskaźnika rozwoju społeczno-gospodarczego, w 2010 było 138 takich jednostek, w 2015 zaś 143. Ogółem na przestrzeni 10 lat analizy 30 gmin zachowało zgodność w przyporządkowaniu do typu skupienia w odniesieniu zarówno do miary rozwoju demograficznego, jak i społeczno-gospodarczego. W grupie tej znajdują się głównie gminy miejsko-wiejskie z terenu województwa lubelskiego, zaś zgodność przyporządkowania dotyczy w ich przypadku przede wszystkim klastra niskich wartości (LL). Na przestrzeni kolejnych lat analizy można zauważyć, iż spójność w odniesieniu do cech demograficznych i społeczno-ekonomicznych dotyczy w szczególności gmin o jednorodnie niskim poziomie cechy należących do klastrów typu LL. W 2005 spośród 50 gmin o spójnej klasyfikacji 38 jednostek, tj. 76\%, należało do tej grupy wobec 9 (18\%) należących do klastra wysokich wartości (HH) oraz 3 (6\%) tworzących hot-spoty. Proporcje te uległy zmianie w kolejnych latach analizy. W 201082 (60\%) gminy o jednolitej klasyfikacji w odniesieniu do cech demograficznych i społeczno-gospodarczych należały do klastra niskich wartości (LL), jednak liczebność analogicznej grupy podmiotów należących do klastra wysokich wartości (HH) wzrosła do 52 (37\%). Zbliżone proporcje odnotowano w roku $2015-82$ gminy (57\%) były członkami klastrów niskiej wartości dla obu cech, ale jednocześnie 59 jednostek (40\%) było członkami klastra typu HH. W obu badanych okresach znaczenie gmin tworzących hot-spoty w budowaniu spójności pomiędzy cechami demograficznymi i społeczno-gospodarczymi było marginalne (jedynie około 3\% jednostek w łącznej grupie gmin o spójnej klasyfikacji). W wymiarze terytorialnym we wszystkich analizowanych latach większość gmin wykazujących spójność w zakresie cech demograficznych i społeczno-gospodarczych przy niskim poziomie 
wskaźników położona była na terenie województwa lubelskiego, podlaskiego i mazowieckiego, zaś gminy o spójnej klasyfikacji przy wysokim poziomie obu wskaźników położone były na terenie województw: mazowieckiego, wielkopolskiego oraz w mniejszym zakresie pomorskiego i dolnośląskiego. W przypadku województw mazowieckiego i wielkopolskiego gminy o zgodnych klasyfikacjach przy wysokim poziomie cechy położone były w obszarze pasa przylegającego bezpośrednio do stolic województwa (Warszawy i Poznania). Potwierdza to postawioną na wstępie tezę, iż szczególnie duże miasta wywierają istotny wpływ na przestrzenne zróżnicowanie obszarów położonych w przyległej strefie.

\section{Zakończenie}

Przeprowadzona analiza wykazała istnienie dodatniej autokorelacji przestrzennej dla miar rozwoju demograficznego i społeczno-gospodarczego w poszczególnych latach, zaś rosnący poziom globalnej statystyki Morana, w rozpatrywanym okresie 2005-2015, oznacza wzmocnienie zależności przestrzennej. Dla liczebności skupień lokalnych miar statystyki Morana cechami różnicującymi były rodzaj i typ ludnościowy gmin oraz położenie przestrzenne w ujęciu wojewódzkim. Spójność terytorialną $\mathrm{w}$ rozumieniu zgodności w przyporządkowaniu do typu skupienia zarówno w odniesieniu do miary rozwoju demograficznego, jak i społeczno-gospodarczego w całym analizowanym okresie zidentyfikowano w przypadku 30 gmin, głównie gmin miejsko-wiejskich z terenu województwa lubelskiego, dla których zgodność przyporządkowania dotyczy przede wszystkim klastra niskich wartości (LL). Delimitacja spójności gmin w zakresie cech demograficznych i społeczno-gospodarczych przy niskim/wysokim poziomie wskaźników wskazuje na wyraźne zróżnicowanie dla regionów wschodnich i zachodnich Polski.

\section{Literatura}

Anselin L., 1995, Local indicators of spatial association - LISA, Geographical Analysis, vol. 27(2), no. 2, s. 93-115.

Hellwig Z., 1968, Zastosowanie metody taksonomicznej do typologicznego podziału krajów ze względu na poziom ich rozwoju oraz zasoby i strukture wykwalifikowanych kadr, Przegląd Statystyczny, $\mathrm{nr} 4$.

Herbst M., Wójcik P., 2013 Delimitacja dyfuzji rozwoju z miast metropolitalnych z wykorzystaniem korelacji przestrzennej, Studia Regionalne i Lokalne, nr 4(54), s. 6-21. ISSN 1509-4995, doi: 10.7366/1509499545401.

Janc K., 2006, Zjawisko autokorelacji przestrzennej na przykładzie statystyki I Morana oraz lokalnych wskaźników zależności przestrzennej (LISA) - wybrane zagadnienia metodyczne, Dokumentacja Geograficzna, nr 33, Idee i praktyczny uniwersalizm geografii, red. T. Komornicki, Z. Podgórski, IGiPZ PAN, Warszawa, s. 76-83.

King B.M., Minium E.W., 2009, Statystyka dla psychologów i pedagogów, Wydawnictwo Naukowe PWN, Warszawa. 
Kopczewska K., 2006, Ekonometria i statystyka przestrzenna z wykorzystaniem programu $R$ CRAN, CeDeWu, Warszawa.

Myrdal G., 1958, Teoria ekonomii a kraje gospodarczo nierozwinięte, Polskie Wydawnictwa Gospodarcze, Warszawa.

Polski J., 2015, Spójność terytorialna jako podstawa polityki regionalnej, Prace Naukowe Uniwersytetu Ekonomicznego we Wrocławiu, nr 392, Gospodarka Regionalna w Teorii i Praktyce, s. 74-80. DOI: $10.15611 / \mathrm{pn} .2015 .392 .08$.

Ryszkiewicz A., 2013, Od konwergencji do spójności i efektywności. Podstawy teoretyczne polityki spójności gospodarczej, społecznej i terytorialnej Unii Europejskiej, Oficyna Wydawnicza, Szkoła Główna Handlowa w Warszawie, Warszawa. 